\title{
A ANÁliSE DA TUTELA DA IMPORTUNAÇÃO SEXUAL NO ORDENAMENTO PENAL BRASILEIRO
}

\section{ANALYSIS OF THE PROTECTION OF SEXUAL IMPORTUNATION IN BRAZILIAN CRIMINAL ORDER}

\section{Débora Cunha Azevedo*}

\begin{abstract}
Resumo
A presente monografia trata-se de uma pesquisa acerca do tipo penal denominado "importunação sexual", o qual se propõe a tutelar atos libidinosos ocorridos sem o consentimento da vítima, em que o agressor deseja satisfazer a sua própria lascívia ou a de outrem. O referido delito foi sancionado e entrou em vigor em 24 de setembro de 2018, através da Lei $\mathrm{n}^{\mathbf{0}}$ 13.718/2018. A necessidade de sua criação adveio de vários casos de mulheres que foram sexualmente violadas em transporte públicos pelo país, o mais conhecido ocorreu em 2017, em que o agressor ejaculou em uma mulher usuária deste tipo de transporte em São Paulo. Contudo, havia uma lacuna na norma penal, os delitos até então tipificados não eram, de todo, adequados para tutelar a conduta criminosa acima citada, o que ensejou a criação do tipo da "importunação sexual".
\end{abstract}

Palavras-chave: Importunação sexual. Bem jurídico. Liberdade sexual. Lacuna.

\begin{abstract}
This monograph deals with a research on the criminal type called "sexual harassment", which lends itself to guarding libidinous acts that occurred without the consent of the victim, in which the aggressor wishes to satisfy his own or others lust. The aforementioned offense was sanctioned and entered into force recently on September 24, 2018, through Law No. 13.718 / 2018. The need for its creation came after several cases of women who were sexually abused in public transportation by the country, the best known occurred in 2017, in which the aggressor ejaculated in a woman who was user of this type of transportation in São Paulo. However, there was a blank in the criminal law, the crimes that were defined in respective code were not at all adequate to protect the criminal conduct mentioned above, which led to the creation of the delict: "sexual harassment."
\end{abstract}

Keywords: Sexual harassment. Legal good. Sexual freedom. Blank.

Artigo Submetido em 15 de Outubro de 2019 e aprovado em 16 de Novembro de 2019.

*Aluna de Graduação em Direito da Pontifícia Universidade Católica de Minas Gerais. Email: deboracunhaazevedo@gmail.com 


\section{INTRODUÇÃO}

Em uma pesquisa realizada pela ActionAid -organização internacional que trabalha por justiça social, igualdade de gênero e pelo fim da pobreza- apontou que, $86 \%$ (oitenta e seis por cento) das brasileiras entrevistadas já haviam passado por algum tipo de assédio sexual em espaços urbanos. Abrangendo desde mulheres que sofreram com comentários de cunho sexual, àquelas que já tiveram seus corpos tocados sem prévia anuência e até mesmo, algumas que tinham sido estupradas.

Em 2017 ocorreu um caso que teve grande repercussão na mídia brasileira e que refletiu o cenário acima apresentado. Diego Novais, de 27 anos, ejaculou no pescoço de uma mulher dentro de um transporte público no estado de São Paulo. Pelo que foi preso, mas posteriormente solto e na mesma semana voltou a cometer novo ilícito ao se "esfregar" em outra usuária do transporte público paulista.

$\mathrm{O}$ acontecimento deixou a mostra uma lacuna que existia em nosso ordenamento penal. Pois, se por ventura o evento fosse tratado como estupro, a pena de 6 (seis) a 10 (dez) anos seria alta ante a gravidade da conduta tida por Diego, se comparada, por exemplo, à uma conjunção carnal forçada com emprego de violência.

Outra infração possível de enquadramento à época seria a "importunação ofensiva ao pudor", que não chegava nem mesmo a ser crime, era uma contravenção penal, que previa apenas pena de multa. $\mathrm{O}$ que também, pela pena ser tão baixa, foi defendida por alguns como inadequada. O que será demonstrado ao longo do trabalho.

Dessa forma, o legislativo brasileiro se viu diante de um impasse, para o qual uma possível solução seria a criação de um novo tipo penal intermediário. Exatamente o que foi feito. Em 24 de setembro de 2018 foi sancionada e entrou em vigor a Lei $n^{\circ} 13.718$ de 2018 que tipificou o delito da importunação sexual, previsto no art. 215-A do Código Penal, sob a seguinte redação: "praticar contra alguém e sem a sua anuência ato libidinoso com o objetivo de satisfazer a própria lascívia ou a de terceiro: "Pena - reclusão, de 1 (um) a 5 (cinco) anos, se o ato não constitui crime mais grave." (BRASIL, 2018).

O presente artigo visa estudar esse novo tipo penal sob o questionamento: a importunação sexual atende a proteção do bem jurídico que se propõe?

Dessa forma, para que essa pergunta fosse respondida, o trabalho perpassou o histórico dos crimes sexuais, demonstrou qual o bem jurídico a importunação sexual visa proteger, além de analisar a história da criação do tipo em voga e os seus aspectos jurídicos, bem como a sua aplicação prática e a dos tipos correlatos. 


\section{HISTÓRICO DOS CRIMES SEXUAIS}

Conforme preceitua Bitencourt (2016), no Direito Romano já havia previsão de crimes sexuais, com rigorosas penas para aqueles considerados violentos, em destaque, o estupro, que possuía pena de morte. Na Idade Média não foi diferente, a pena capital ainda estava em vigor, assim como nas Ordenações Filipinas.

Ainda de acordo com o autor acima citado, no que tange o histórico desses delitos no Direito brasileiro, tem-se que o primeiro Código Penal do nosso país, o de 1830, sancionado alguns meses antes de Dom Pedro I se abdicar do trono, previa a pena de prisão de três a doze anos para o crime de estupro violento e ainda, fato curioso, o agente tinha que adotar a vítima. Em 1890 a pena foi reduzida, passando para prisão de um a seis anos, denominada à época, de celular - espécie de confinamento solitário- e também tinha que pagar para a vítima uma quantia de bens e dinheiro (BITENCOURT, 2016).

Sobre a legislação brasileira tratada, conforme Bitencourt:

O Código Criminal de 1830 punia a ofensa pessoal para fim libidinoso que causasse dor ou mal corpóreo, mesmo que não tivesse havido cópula carnal (art.223). O Código Penal de 1890, por sua vez, punia o atentado violento ao pudor com a pena de um a três anos de prisão celular (art. 226). (BITENCOURT, 2016, p. 49).

No tocante ao cenário brasileiro, tem-se que a liberdade sexual nem sempre foi reconhecida como um bem jurídico individual. Foi um longo caminho até que isso se desse, até porque a cultura patriarcal sempre foi predominante, assim, a liberdade sexual das mulheres não era reconhecida.

A mencionada cultura machista e patriarcal pode ser facilmente visualizada por meio do nosso histórico legal. Até a reforma do Código Penal em 2005 vários tipos penais traziam como elementar a chamada "mulher honesta", caso tal elementar não fosse comprovada, o delito não restava configurado. Um exemplo que demonstra tal situação é o que estabelecia o crime de rapto, o qual era previsto no art. 219 doCódigo Penal e dispunha que: "Raptar mulher honesta, mediante violência, grave ameaça ou fraude, para fim libidinoso: Pena reclusão, de dois a quatro anos." (BRASIL, 1940).

Ainda nesse cenário, a virgindade da mulher era vista como uma preciosidade, algo de estimado valor. Denotação demonstrada pelo crime de "sedução". A ideia defendida era a de que tipificações desse gênero seriam para a proteção feminina. Contudo, percebe-se que tudo isso contribuía para uma desvalorização e inferiorização da mulher. É o que defende Torres: 
[...] como consagração da ideologia patriarcal no âmbito do sistema penal brasileiro, a virgindade da mulher era considerada como um bem ou um valor, que, na sua dimensão jurídica e social, era merecedor de proteção, como ocorria na criminalização da sedução (Código Penal, artigo 217. Seduzir mulher virgem, menor de dezoito anos e maior de catorze, e ter com ela conjunção carnal, aproveitando-se de sua inexperiência ou justificável confiança: Pena de reclusão, de dois a quatro anos). E, obviamente, a previsão desse crime não visava à proteção das mulheres, como enganadamente era afirmado. Tratava-se, na realidade, de uma verdadeira capitis de minucia para elas. (TORRES, 2011, p. 185).

Os tipos acima descritos foram revogados com a reforma de 2005, mas a sexualidade continuou vinculada à moralidade pública e aos costumes. Prova disso é que o título no Código Penal continuou sendo: “dos crimes contra os costumes".

Nesse sentido, vejamos:

[...] apesar da extinção desses dispositivos androcêntricos, revogados apenas em 2005, o sistema penal brasileiro continuou convivendo com a ultrapassada concepção de que a sexualidade deveria ser controlada por uma pauta moral de comportamento, segundo padrões ditados pela ideologia patriarcal. Assim, os delitos contra a liberdade sexual continuaram inseridos no capítulo dos crimes contra os costumes. E foi somente no final da primeira década do século XXI, com a aprovação da Lei n. 12.015, de 7 de agosto de 2009, que a sexualidade foi reconhecida como um atributo da pessoa humana e como uma expressão de sua dignidade: essa lei abandonou a antiga e patriarcal concepção de crimes contra os costumes e passou a cuidar da proteção da sexualidade no âmbito da dignidade sexual. (COSTA, 2010, p. 30).

Mudanças mais expressivas só foram visualizadas na reforma que ocorreu em 2009, com a Lei $n^{\circ} 12.015 / 2009$. Somente à partir dessa lei os crimes sexuais foram reconhecidos como intrínsecos à dignidade da pessoa humana, passando a ser previstos sob o título: “dos crimes contra a dignidade sexual", deixando de lado o viés moral a que se relacionavam.

Outra mudança significativa ocorrida com a reforma de 2009 se deu com a alteração do delito de estupro, os crimes de estupro e atentado violento ao pudor se uniram. Dessa forma, a redação passou a ser: “Art. 213. Constranger alguém, mediante violência ou grave ameaça, a ter conjunção carnal ou a praticar ou permitir que com ele se pratique outro ato libidinoso.” (BRASIL, 2009).

A conjunção carnal no sentido legal é a cópula, primeira modalidade, resultado de uma relação heterossexual de conjunção carnal entre órgãos sexuais masculinos e femininos. $\mathrm{O}$ ato libidinoso, segunda modalidade, diverso da conjunção carnal, é, por sua natureza, conteúdo e significado, traduzido na intenção de o sujeito ativo despertar ou satisfazer em si ou em outrem a própria concupiscência. (COSTA, 2010, p. 42).

Antes dessa modificação, o crime de estupro se referia apenas à conjunção carnal. $\mathrm{O}$ problema é que este somente restava-se configurado se o laudo constatasse a ocorrência da 
relação. Porém, como se sabe, muitas vezes o laudo é prejudicado em razão da demora para sua realização, tendo em vista que a vítima pode ter vergonha e somente depois de algum tempo procurar ajuda, ou então, a vítima pode tomar banho e retirar de seu corpo o material genético do agressor.

Desse modo, tendo em vista que o ato libidinoso era um tipo apartado, ele podia ser demonstrado através da palavra dos envolvidos ou até, de provas testemunhais. Sendo pouco provável a realização de exames, como ainda o é. Contudo, a pena deste delito era mais branda. Assim, com a reforma de 2009, a questão da prova ficou um pouco mais complicada. Pois, além do ato libidinoso dificilmente poder ser comprovado através de laudo, agora, como estupro, sua pena é ainda mais alta. É o que defendem Dias e Joaquim:

\begin{abstract}
A prova do ato libidinoso consistia em evidenciar o ato alegado pela vítima, que poderia ser o coito anal, o sexo oral, ou até mesmo o beijo lascivo e normalmente fazia se uso de provas testemunhais e da palavra das partes, sendo rara a possibilidade de exame de corpo de delito, permanecendo tão frágil quanto agora, no entanto a pena era mais branda. (DIAS; JOAQUIM, 2013, p. 292).
\end{abstract}

Ainda em relação à reforma de 2009, salienta-se que, tendo em vista a busca pela efetivação do Princípio da Igualdade, previsto na Constituição Federal de 1988, o sujeito passivo do crime de estupro deixou de ser apenas a mulher. Como bem leciona o professor e juiz, José Henrique Torres:

\begin{abstract}
Além disso, outras alterações legislativas no sistema penal foram aprovadas em 2009 com o objetivo de afastar aquela indesejável concepção patriarcal de sexualidade. Lembre-se, por exemplo, de que, para consagrar o princípio constitucional da igualdade entre homens e mulheres, corolário da dignidade humana, eliminou-se do crime de estupro a referência à mulher como vítima exclusiva desse delito. (TORRES, 2011, p. 186).
\end{abstract}

Outro ponto que merece destaque sobre a reforma em questão é quanto a evidenciada preocupação do legislador em dar maior proteção às crianças e adolescentes, passando a prever o tipo de "estupro de vulnerável." Assim:

A Lei n ${ }^{\circ}$ 12.015, de 7 de agosto de 2009 (Reforma de 2009), objetivando reforçar a proteção da vítima vulnerável no amplo espectro da dignidade humana, cria três tipos penais: a) estupro de vulnerável;17 b) satisfação da lascívia mediante presença de criança ou adolescente; 18 c) favorecimento da prostituição ou outra forma de exploração sexual de vulnerável;19 e, no seu art. 5º acrescenta o art. 244-B do Estatuto da Criança e do Adolescente, revogando a Lei $\mathrm{n}^{\circ} 2.254$, de $1^{\circ}$ de julho de 1954, ao alargar o núcleo protetivo normativo de "quem pratica as condutas tipificadas utilizando-se de quaisquer meios eletrônicos, inclusive salas de bate-papo da internet", com a causa de especial aumento de pena de uma terça parte quando o injusto for do tipo das equiparadas aos hediondos.

O objeto jurídico da tutela é a liberdade e autodeterminação sexual dos menores, em 
razão da faixa etária da vítima- de 14 (catorze) anos de idade -, mesmo com o consentimento expresso ou tácito, visto que pode prejudicar gravemente o livre desenvolvimento de sua personalidade. (COSTA, 2010, p. 32).

Em observância ao que foi narrado, restou evidente que somente com a reforma de 2009 a liberdade sexual passou a ser reconhecida. A qual se traduz pelo poder que homens e mulheres têm de escolherem se desejam ou não se relacionarem e mais ainda, com quem. Ou seja, ambos têm o direito de recusarem a práticas de atos lascivos ou sexuais, mesmo que seja com seus próprios cônjuges. Nesse sentido dispõe Bitencourt:

Enfim, o presente tipo penal, a partir da redação determinada pela Lei $\mathrm{n}$. $12.015 / 2009$, insere-se na finalidade abrangente de garantir a todo ser humano, que tenha capacidade de auto determinar-se sexualmente, que o faça com liberdade de escolha e vontade consciente; pretende-se, em outros termos, assegurar que a atividade sexual humana seja realizada livremente por todos. (BITENCOURT, 2014, p. 48).

Nessa linha de raciocínio, Costa (2010) dispõe sobre a importância do bem jurídico tutelado - liberdade sexual- a partir da reforma de 2009. Demonstrando que este em nada diz respeito a preceitos morais e costumeiros.

\begin{abstract}
A liberdade é um poder de autodeterminação, em razão do qual a pessoa humana escolhe por si própria seu comportamento pessoal. A liberdade sexual, entendida como uma de suas mais importantes expressões, referida ao exercício da sua própria sexualidade, se constitui no direito de exercê-la em liberdade. Note-se que se cogita de um valor intrinsecamente individual desconectado de fundamentos ético-sociais ou de sentimentos gerais de moralidade sexual. (COSTA, 2010, p. 29).
\end{abstract}

Tem-se que, a reforma de 2009 foi relevante ao alterar o título de "dos crimes contra os costumes" para "dos crimes contra a dignidade sexual." Uma vez que primeiro não se mostrava adequado, tendo em vista o bem jurídico que os delitos de cunho sexual protegem. É o que leciona Bitencourt:
A impropriedade do Título "Dos crimes contra os costumes" já era reconhecida nos idos de 1940, pois não correspondia aos bens jurídicos que pretendia tutelar, violando o princípio de que as rubricas devem expressar e identificar os bens jurídicos protegidos em seus diferentes preceitos. (BITENCOURT, 2016. p. 43).

Nucci também sustenta que o título mantido até a reforma de 2009 não condizia com o bem jurídico tutelado, defendendo que ele deveria ter sido alterado até antes, como na reforma de 2005 e assim, poder transparecer o bem jurídico que de fato condiz com o ordenamento, que é a dignidade sexual, da qual deriva a liberdade sexual. Desse modo: 
[...] perdeu o legislador a oportunidade de, por intermédio da Lei ${ }^{\circ} 11.106$, de 28 de março de 2005, modificar a redação do Título VI do Código Penal. A importância de tal modificação residiria no fato de que, por meio das seçõescapítulos e títulos do Código Penal, o intérprete conseguiria identificar o bem juridicamente protegido. Tendo em vista que o Código Penal usa a expressão crimes contra os costumes, devemos concluir serem os bens a ele ligados que almeja proteger por meio da criação típica. No entanto, embora não se possa descartar totalmente os costumes, podemos reinterpretar tal expressão de acordo com os ditames da Constituição Federal, tendo como foco central do nosso raciocínio a dignidade da pessoal humana, aqui entendida no seu sentido mais íntimo, vale dizer, da liberdade sexual, isto é, a capacidade que a pessoa tem de dispor, livremente, sobre o seu próprio corpo, devendo ser punido qualquer comportamento que, de alguma forma, agrida a sua vontade. (NUCCI, 2008, p. 859).

Por mais que a sexualidade só tenha sido vista como inerente à dignidade humana com a reforma de 2009, a Constituição Federal há vinte e um anos já previa o Princípio da Dignidade da Pessoa Humana, que em tese, deveria se aplicar em todos os setores do ordenamento jurídico, haja vista que a Constituição é nossa norma maior, sendo todas as demais subordinadas à ela. Conforme Torres:

\footnotetext{
Mas, não se olvide que, desde a promulgação da Constituição de 1988, a dignidade humana já era reconhecida pela sociedade brasileira como um princípio fundamental e norteador de todo o sistema jurídico, político e social do nosso país. E a sexualidade, como atributo da pessoa humana, já deveria ter sido, desde então, submetida à proteção no âmbito da dignidade humana. (TORRES, 2011, p. 186).
}

Em 1994, na denominada Conferência de Cairo, ficou decidido que a sexualidade das mulheres não seria mais controlada por uma cultura patriarcal. Logo em seguida, em 1995, na Conferência de Bejing, da qual o Brasil fez parte, restou reconhecidos os Direitos Sexuais e Reprodutivos femininos, além da grande ênfase que foi dada acerca da igualdade sexual, autonomia e liberdade das mulheres. Vejamos:

[...] na Conferência do Cairo (1994), ficou afirmado o compromisso do sistema de Direitos Humanos com a necessidade do abandono da concepção patriarcal de controle da sexualidade das mulheres. E, na Conferência de Beijing (1995), foram expressamente reconhecidos os Direitos Sexuais e Reprodutivos e enfatizada a necessidade da garantia da autodeterminação, da igualdade e da segurança sexual e reprodutiva das mulheres para a plena vivência de sua saúde sexual e reprodutiva, estabelecendo-se que os Estados-Partes, como o Brasil, têm o dever de proteger tais direitos. (TORRES, 2011, p. 186).

É perceptível que foi longo o caminho até que se chegasse a uma alteração da legislação no sentido de tentar reduzir, mesmo que minimamente, o machismo e a inferiorização da sexualidade feminina tão arraigados à nossa cultura. Torres explana que:

Assim, para que as mulheres não continuem acorrentadas ao antigo paradigma 
patriarcal, e recebam a proteção que o sistema constitucional exige, é preciso aproximar a mão do coração, ou seja, é preciso transformar em ações concretas os dispositivos legais que, no âmbito meramente formal, garantem o exercício da sexualidade como um atributo da dignidade humana. (TORRES, 2011, p. 199).

\section{DA IMPORTUNAÇÃO SEXUAL}

\subsection{Histórico acerca da criação do tipo "Importunação Sexual"}

Em 2015 a Senadora Vanessa Grazziotin apresentou o Projeto de Lei no 618/2015, o qual previa acrescentar o estupro coletivo como uma causa de aumento do crime de estupro, previsto no Código Penal. (BRASIL, 2015).

A referida causa de aumento seria tipificada como o art. 225-A, que possuía a seguinte redação: "Nos casos dos arts. 213 e 217-A deste Código, a pena é aumentada de um terço se o crime é cometido em concurso de duas ou mais pessoas." (BRASIL, 2015).

Já em 2016, o Senador Ataídes Oliveira propôs a emenda para que a pena fosse ainda mais rigorosa, sendo assim a redação seria: “Art. 225-B. Nas hipóteses elencadas no artigo anterior, a pena será aumentada em três quintos se o crime for cometido em concurso de cinco ou mais pessoas.” (BRASIL, 2016).

Ainda em 2016 a Comissão de Constituição, Justiça e Cidadania emitiu o parecer de $\mathrm{n}^{\circ}$ 524 , entendendo que a pena deveria ser elástica, para possibilitar ao juiz aumentar a pena de acordo com a gravidade do caso. Assim, o mínimo seria de um terço e o máximo de dois terços, previsão que de fato entrou em vigor com a Lei nº13.718/18. No parecer também continha a defesa de ser tipificado o delito de divulgação de cena de estupro, com a seguinte redação:

Divulgar por qualquer meio, inclusive por meio de sistema de informática ou telemático, fotografia, vídeo ou outro registro que contenha cenas de estupro, de modo a solucionar a lacuna da lei, que apenas previa tal tipificação em relação à vítimas crianças e adolescentes. (BRASIL, 2016).

Consta do parecer:

A divulgação do estupro e, a partir desse momento, sua virtualmente eterna permanência na internet, não gera apenas prejuízos morais à vítima, a exemplo de um xingamento ou de uma mera depreciação pessoal. A divulgação perturbará seu convívio familiar, desestabilizará suas relações sociais, deixará sequelas em futuros relacionamentos amorosos e na imagem que a vítima buscará construir a respeito de si mesma. $\mathrm{O}$ estigma de mulher estuprada - e os inevitáveis e cruéis julgamentos morais daqueles que buscam justificar o estupro a partir do comportamento da vítima - a acompanhará por toda a vida, pois o conteúdo que está na rede dificilmente será eliminado de forma permanente. (BRASIL, 2016). 
Sendo assim o Projeto de Lei saiu do Senado prevendo o acréscimo ao Código Penal dos arts. 218-C e 225-A. Ou seja, a tipificação do crime de divulgação de cena de estupro e a previsão da causa de aumento de pena para o crime de estupro cometido por duas ou mais pessoas - estupro coletivo- (BRASIL, 2015).

Em 01 de junho de 2016 o Projeto foi encaminhado à Câmara dos Deputados, que reconheceu pertinente acrescentar ao Código Penal as propostas formuladas pelo Senado causa de aumento em razão do estupro coletivo e o crime de Divulgação de cena de estupro ou de cena de estupro de vulnerável, de cena de sexo ou de pornografia- e ainda criaram mais três tipos penais: induzimento ou instigação a crime contra a dignidade sexual, incitação ou apologia de crime contra a dignidade sexual e o de importunação sexual, o qual estabelece: "Praticar, na presença de alguém e sem a sua anuência, ato libidinoso, com o objetivo de satisfazer a própria lascívia ou a de terceiro, com a pena de reclusão, de um a cinco anos, se o ato não constituir crime mais grave.” (BRASIL, 1940)

A Câmara dos Deputados aprovou o PL em questão no dia sete de março de 2018 em homenagem ao dia das mulheres, que é comemorado no dia oito de março de todo ano. A bancada era composta apenas por deputadas. Na ocasião, também foram aprovados demais projetos da bancada feminina.

Desse modo, após a revisão da Câmara dos Deputados o PL foi complementado e conforme ementa, passou a prever:

Tipifica os crimes de importunação sexual e de divulgação de cena de estupro; altera
para pública incondicionada a natureza da ação penal dos crimes contra a dignidade
sexual; estabelece causas de aumento de pena para esses crimes; cria formas
qualificadas dos crimes de incitação ao crime e de apologia de crime ou criminoso; e
revoga dispositivo do Decreto-Lei $\mathrm{n}^{\circ}$ 3.688, de 3 de outubro de 1941 (Lei das
Contravenções Penais). (BRASIL, 2016).

Em 24 de setembro de 2018, com o sancionamento da Lei ${ }^{\circ}$ 13.718/2018, pelo então presidente do STF, Dias Toffoli, entrou em vigor o delito da importunação sexual.

Cumpre salientar que no caso, a lei foi sancionada pelo presidente do STF, que assumia o cargo de presidente interino, tendo em vista que o presidente da república, Michel Temer, estava fora do país. A Constituição Federal dispõe em seu art.80 que na falta do presidente da República, o vice assume suas funções, e sucessivamente o presidente da Câmara dos Deputados, do Senado e o do STF. No caso, não havia vice-presidente e os presidentes da Câmara e do Senado estavam impedidos de assumir o cargo, ante a proibição da lei eleitoral de candidatos à reeleição assumir a cadeira presidencial. 
A razão de se criar o delito da importunação sexual surgiu de vários ocorridos que repercutiram na mídia e que apresentam o mesmo traço característico: pessoas, que sem violência ou grave ameaça, cometem condutas de cunho sexual, para satisfazer sua própria lascívia, sem o consentimento das vítimas, de modo a ofender a moral destas, que em regra, são mulheres. Atos que se realizam por meio de "encoxadas", ejaculação furtiva, apalpamento de áreas íntimas, entre outros.

Recentemente, um dos acontecimentos de grande repercussão, foi envolvendoDiego Ferreira de Novais, de 27 (vinte e sete) anos, que em 28 de agostode 2017, ejaculou no pescoço de uma mulher dentro de um transporte público em São Paulo, conforme noticiou o G1 São Paulo (2017). ${ }^{1}$ No mesmo veículo de informação, consta que o Juiz do Tribunal de Justiça de São Paulo, José Eugênio Souza Neto, entendeu que a infração cometida foi a contravenção penal de importunação ofensiva ao pudor e não estupro, o que causou revolta em várias pessoas, que se manifestaram por meio de redes sociais e demais veículos de comunicação, entendendo que a decisão tomada pelo juiz foi desproporcional ante a gravidade do caso.

Como podemos perceber através do que declarou, à época dos fatos, a ex professora de Direito Penal da Fundação Getúlio Vargas e doutora em direito humanos, Zapater:

\begin{abstract}
Eu entendo que houve estupro na conduta de qualquer outro ato libidinoso, teve contato físico. Não concordo com a decisão judicial que não reconhece nem violência nem constrangimento. Acho que havendo ali esse contato físico não dá para dizer que é só uma importunação ao pudor. O emprego do constrangimento na lei tem significado de obrigar, não de deixar a pessoa envergonhada. Ainda mais nesse sentido, acho que não tem como dizer que a vítima não foi constrangida, que ela não tenha sido obrigada a levar um jato de esperma no pescoço. No meu entender, o caso configura estupro. (LIMA, 2017).
\end{abstract}

Através de nota pública, o presidente do Tribunal de Justiça de São Paulo (TJSP) reconheceu ter sido acertada a decisão do magistrado José Eugênio. Conforme percebemos em um trecho retirado da referida nota:

Diante da grande repercussão na imprensa e nas redes sociais da decisão proferida em audiência de custódia realizada no dia 30, sobre a prisão de Diego Ferreira de Novais, o TJSP esclarece que o juiz do caso, após ouvir o Ministério Público, concluiu não se tratar de hipótese em que o artigo 313 do Código de Processo Penal - na forma que lhe deu a Lei $n^{\circ} 12.403 / 11$ - autorizasse a conversão da prisão em flagrante em prisão preventiva. Essa decisão, tomada estritamente dentro dos limites da independência assegurada ao juiz como forma de garantir a liberdade pública, está sujeita ao controle recursal previsto na própria lei processual.

\footnotetext{
${ }^{1}$ Cumpre esclarecer que não foi utilizada fonte oficial haja vista que o processo encontra-se em tramitação sob o regime de segredo justiça.
} 
Seus termos não impedem que o acusado seja denunciado por crime mais grave e que a prisão venha a ser decretada em momento processual subsequente, caso haja elementos para tanto. (SÃO PAULO, 2017).

Sobre a criação do novo delito e seus respectivos motivos, Bitencourt (2018) dispõe que:

Essas ações de indivíduos inescrupulosos, por exemplo, ejaculando, furtivamente, nas vítimas no interior de coletivos (trens, metrôs, ônibus etc.) não encontravam adequação típica nas molduras penais em vigor, vagando no universo sócio-jurídico brasileiro à procura de um tipo penal até então inexistente. (BITENCOURT, 2018).

Além do mais, conforme se expressa, Bitencourt (2018) deixa claro que o fato ocorrido em São Paulo não é único e isolado, aliás, casos que configuram importunação sexual é mais comum de ocorrer do que se pensa:

\begin{abstract}
Os fatos do quotidiano não param de surpreender o legislador, que é incapaz de prever todas as condutas possíveis para criminalizá-las. Quando se poderia imaginar alguém ejaculando, furtivamente, no pescoço de uma distraída senhora no interior de um veículo coletivo, como ocorreu na cidade de São Paulo? Sabe-se agora que este caso do ônibus ocorrido em São Paulo (agosto de 2017), não foi o único, pelo contrário, sua prática é muito mais frequente do que se pode imaginar. (BITENCOURT, 2018).
\end{abstract}

Somente a título de curiosidade, conforme noticiado pela Folha de São Paulo, nos três primeiros dias após a lei ser sancionada, só em São Pauloforam registrados 29 (vinte nove) casos de importunação sexual (MAGNENTI, 2018).

\title{
3.2 Análise jurídica do crime de Importunação Sexual
}

Partindo para a análise das características do tipo em comento, tem-se que, quanto aos sujeitos trata-se de crime comum, que pode ser praticado (sujeito ativo) ou sofrido (sujeito passivo) por qualquer agente, sem que deste se exija uma condição especial. Contudo, é importante salientar que na grande maioria das vezes o sujeito passivo será uma mulher. É o que Bitencourt (2018) deixa claro em seu exame sobre o delito em voga:

Sujeito ativo, como crime comum, pode ser praticado ou sofrido indistintamente por homem ou mulher, sendo indiferente o gênero do sujeito ativo e do sujeito passivo, inclusive por ex-maridos, ex-namorados ou ex-companheiros após o término da relação, e, nesta última hipótese, ganha especial relevo a ausência de consentimento da vítima. Sujeito passivo, igualmente, pode ser, independentemente, homem ou mulher, embora seja mais comum as mulheres estarem mais sujeitas a essa exposição e até pela natureza feminina correm mais riscos de serem exploradas, abusadas e até humilhadas por indivíduos inescrupulosos, em quaisquer circunstâncias. As pessoas do sexo feminino estão mais sujeitas a violações dessa natureza, inclusive em términos de relações afetivo-sexuais, inclusive por vingança. (BITENCOURT, 2018) 
Sabendo que qualquer indivíduo pode cometer o crime em comento, resta saber qual a conduta necessária para incidir no tipo. Observa-se que o crime é de ação única, que segundo Bitencourt é aquele que contém somente uma modalidade de conduta, expressa pelo verbo núcleo do tipo (BITENCOURT, 2016, p. 109). Dessa forma, comete o crime aquele que pratica, na presença de alguém (vítima), algum ato, queindubitavelmente, seja para satisfazer sua lascívia ou a de outrem. Desde que, sem a concordância da vítima. Como por exemplo: ejacular em alguém, colocar a mão dentro de sua roupa, apalpar partes íntimas, tudo sem o consentimento da vítima. É o que fica claro com a explanação de Bitencourt:

O tipo descrito no artigo 215-A prevê uma única modalidade de conduta delituosa, qual seja, praticar — na presença de alguém —, isto é, na presença da vítima, qualquer ato libidinagem, como é o caso do exemplo clássico, ejacular na presença, ou na própria vítima, como ocorreu no interior de coletivos urbanos deste país. Assemelha-se a essa conduta — e, por isso mesmo, está abrangida por este tipo penal - quando alguém, sem que a vítima perceba ou contra o seu assentimento, apalpe as suas regiões pudendas (nádegas, seios, pernas, genitália etc.), beijo forçado etc., cuja forma de execução traz consigo a presença inequívoca da vontade consciente de satisfazer a própria lascívia ou a de outrem. [...] Em outros termos, o agente desrespeita a presença de alguém e pratica, sem sua anuência, ato libidinoso buscando satisfazer sua própria lascívia ou a de terceiro. $\mathrm{Na}$ verdade, o agente aproveita-se da presença de alguém (a vítima) e, de inopino, o surpreende, e sem sua anuência, pratica ato libidinoso, ofendendo-lhe a liberdade e a dignidade sexuais. (BITENCOURT, 2018).

Cumpre destacar, para melhor entendimento acerca do tipo, o que seria "lascívia." Segundo o que dispõe Nucci, em seu Manual de Direito Penal (2014), lascívia é: "luxúria, prazer sexual é saciar o prazer sexual ou a sensualidade de outra pessoa, homem ou mulher, de qualquer maneira". (NUCCI, 2014, p. 699-710).

É crucial, para que o crime reste configurado, que esteja presente a elementar do tipo: "ausência do consentimento da vítima," caso contrário, o fato se torna atípico. Vejamos:

[...] Dito de outra forma, se houver consentimento ou anuência da vítima na prática do ato libidinoso não haverá crime, pois o que o caracteriza é a sua prática sem a anuência daquela. Com efeito, havendo o seu assentimento não estará contrariando ou ofendendo a sua liberdade e dignidade sexuais. A existência de consentimento na prática de ato libidinoso, na sua presença, afasta a violação à sua liberdade e à sua dignidade sexuais, não se adequando, portanto, à descrição típica. (BITENCOURT, 2018).

Para Bitencourt (2018) e conforme o sentido trazido pelos dicionários, a elementar do tipo: “estar na presença de alguém”, significa que a vítima precisa estar presente fisicamente no local do crime. Não havendo possibilidade que o delito seja praticado através de algum meio tecnológico, como por videochamada. 


\begin{abstract}
O texto legal utiliza os vocábulos "na presença de alguém" e "sem a sua anuência", ou seja, com a locução "na presença de alguém" fica claro que o fendido, de qualquer gênero, deve encontrar-se, fisicamente, no local onde se realiza o ato libidinoso. Referido vocábulo têm significado muito específico, iniludível de que o ofendido deve estar, pessoalmente, in loco, ou, dito de outra forma, deve estar "de corpo presente" onde se desenrola o ato libidinoso. Em outros termos, na presença de alguém, significa ante alguém que está presente, alguém que vê ou assiste in loco e na hora em que é praticado, e não, indiretamente, via qualquer mecanismo tecnológico, físico ou virtual, como permitiria o mundo tecnológico. (BITENCOURT, 2018).
\end{abstract}

Contudo, tal questão apresenta interpretações distintas, já que Nucci (2009), ao comentar o art. 218-A, delito que também carrega a elementar "na presença de alguém", trás uma idéia contrária àquela apresentada:

\begin{abstract}
Assim não nos parece, pois a evolução tecnológica já propicia a presença — estar em determinado lugar ao mesmo tempo em que algo ocorre — por meio de aparelhos apropriados. Portanto, o menor pode a tudo assistir ou presenciar por meio de câmaras e aparelhos de TV ou monitores. A situação é válida para a configuração do tipo penal, uma vez que não se exige qualquer toque físico em relação à vítima. $\mathrm{A}$ lesão provocada dá-se em nível psicológico, referentemente à sua formação moral e sexual, afetando sua liberdade nesse campo.” (NUCCI, 2009, p. 50).
\end{abstract}

Bitencourt rechaça a interpretação feita por Nucci ao argumento de que fere o Princípio da Taxatividade e o da Tipicidade Estrita, haja vista que o Direito Penal, em razão do Princípio da Legalidade, só pune as ações previamente estabelecidas como crimes. Devese, portanto, considerar apenas o que está descrito no tipo penal, sem que haja uma interpretação além do que está dispõe, ou seja, sem que se puna além do permitido. Destarte:

[...] Essa elasticidade interpretativa não é recepcionada pelo Direito Penal da culpabilidade de um Estado democrático de direito, e tampouco pelo princípio da tipicidade estrita, pois abarcaria condutas não abrangidas pela descrição contida no tipo penal incriminador e, sabido é, que nenhuma norma penal incriminadora admite interpretação extensiva. (BITENCOURT, 2018).

O elemento subjetivo do tipo em questão é doloso, não sendo admitida a forma culposa. $\mathrm{O}$ agente precisa ter a vontade e consciência do que está fazendo, com o especial fim de agir, explicado parágrafos abaixo. Contudo, não basta estar presente o dolo de realizar a conduta descrita no art.215-A, se não restarem presentes todas as elementares do tipo.Dessa forma, para que o tipo se configure, é preciso que todas as elementares sejam atendidas e que esteja patente o dolo do agente. Nesse sentido é o que Bitencourt dispõe:

O elemento subjetivo do crime - importunação sexual — é o dolo constituído pela vontade consciente de praticar a ação descrita no tipo penal, qual seja, praticar, na presença de alguém e sem a sua anuência, ato libidinoso com o objetivo de satisfazer 
a própria lascívia ou a de terceiro. No entanto, o dolo somente se completa com a presença simultânea da consciência e da vontade de todos os elementos constitutivos do tipo penal, mas, principalmente, do não consentimento da vítima. Com efeito, quando o processo intelectual-volitivo não abrange qualquer das elementares constitutivas do tipo penal, o dolo não se completa e sem dolo não se tipifica o crime de importunação sexual, e não há previsão de modalidade culposa. (BITENCOURT, 2018).

O especial fim de agir do tipo em voga é a satisfação da lascívia, seja própria ou de outrem. Dessa forma, o fato do indivíduo ejacular em alguém ou até mesmo apalpar alguma parte íntima da vítima, sem o seu consentimento, não é o fim em si mesmo. A pessoa que possui uma atitude como essa deseja, antes de tudo, satisfazer sua lascívia, por isso ela se constitui como o especial fim de agir do tipo. Ensinamento trazido pelo doutrinador Bitencourt:

O fim especial de satisfazer a própria lascívia (como também a de terceiro) constitui o elemento subjetivo especial do injusto penal e a razão de ser da própria conduta incriminada, aliás, pode-se afirmar, na hipótese de ejaculação, que é a satisfação sexual do agente, não se esgota no ato em si, mas reside, fundamentalmente, na sensação de estar satisfazendo sua lascívia no contato, não autorizado, com outra pessoa, em ambiente público, se expondo para a indefesa vítima, roubando-lhe a satisfação unilateral de sua lascívia ou, eventualmente, também a de terceiro. É como se o agente não se satisfizesse somente com a prática do ato libidinoso propriamente, mas com o fato de ser furtivo, desautorizado e em público. É, pode-se afirmar, verdadeiramente, uma perversão sexual do agente. (BITENCOURT, 2018).

Em relação à pena do delito em tratamento, observa-se que o legislador estipulou a reclusão de 1 (um) a 5 (cinco) anos, se não constituir crime mais grave. Pena bem mais gravosa que aquela que era prevista para a contravenção penal de importunação ofensiva ao pudor (art.61 da LCP, que foi revogado pela mesma lei que instituiu a importunação sexual), que possuía apenas pena de multa, sendo de competência do Juizado Especial Criminal.

Segundo a própria Lei no 9.099 de 1995, alguns dos princípios do Juizado Especial Criminal são os da celeridade e simplicidade. E ainda, sendo o rito sumaríssimo, casos de importunação ofensiva ao pudor eram resolvidos de forma ágil e simplificada.

Tendo em vista que a pena estabelecida para o crime de importunação sexual é mais elevada que aquela que era prevista para o art. 61 da LCP, o delito será processado ante a Justiça Comum e não perante o Juizado. Mas ainda assim, continua sendo possível a aplicação da suspensão condicional do processo, medida despenalizadora prevista na Lei $\mathrm{n}^{\circ}$ 9099/95.

Por outro lado, muito se acredita que a pena do art.61 da LCP não era suficiente para punir o autor na proporção da gravidade da infração cometida. Conforme bem dispõe Bitencourt: 
Sintetizando, pela inexistência de anuência ou de consentimento da vítima, a conduta de ejacular na vítima ou na sua presença, de inopino, configura o crime de importunação sexual e justifica uma pena de dois a cinco anos de reclusão para essa conduta, que objetiva a satisfação da lascívia do autor (ou de terceiro), que age burlando ou dificultando a livre manifestação da vítima, violando a sua liberdade sexual. (BITENCOURT, 2018).

Em contrapartida, enquadrar a ação delituosa em análise enquanto estupro seria desproporcional, no sentido de ser uma pena muito elevada, que se justifica se aplicada a casos mais graves que os de importunação sexual, especialmente na ocorrência da violência ou da grave ameaça. Entendimento que podemos extrair da entrevista dada pela promotora de Justiça e coordenadora do Grupo de Atuação Especial de Enfrentamento à Violência Doméstica (Gevid) do Ministério Público Estadual de São Paulo, Sílvia Chakian, ao site de notícias da Agência Brasil:

A promotora de Justiça e coordenadora do Grupo de Atuação Especial de Enfrentamento à Violência Doméstica (Gevid) do Ministério Público Estadual de São Paulo, Sílvia Chakian, destacou a definição do tipo penal médio da importunação sexual para adequar a conduta dos molestadores, que antes ou eram enquadrados na contravenção mínima prevista para importunação ofensiva ao puder ou no crime hediondo do estupro. "A gente segue um modelo das legislações penais internacionais que contemplam esse tipo penal intermediário e dá resposta a uma sensação muito ruim que a sociedade manifestava, de ineficiência do direito penal, de proteção ineficiente por parte do Estado. Então, a criação desse tipo penal era urgente". (BRITO, 2018a).

\section{A DISTINÇÃO ENTRE A IMPORTUNAÇÃO SEXUAL E OS TIPOS CORRELATOS}

\subsection{Da distinção entre importunação sexual e o estupro}

$\mathrm{O}$ art. 213 do Código Penal prevê que estupro é:“Constranger alguém, mediante violência ou grave ameaça, a ter conjunção carnal ou a praticar ou permitir que com ele se pratique outro ato libidinoso: Pena - reclusão, de 6 (seis) a 10 (dez) anos." (BRASIL, 1940).

Já o art. 215-A do CP (1940), estabelece que importunação sexual é:“Praticar contra alguém e sem a sua anuência ato libidinoso com o objetivo de satisfazer a própria lascívia ou a de terceiro: Pena - reclusão, de 1 (um) a 5 (cinco) anos, se o ato não constitui crime mais grave".

Cumpre esclarecer o que é ato libidinoso, Bitencourt leciona que:

Libidinoso é todo ato lascivo, voluptuoso, que objetiva prazer sexual, aliás, libidinoso é espécie do gênero atos de libidinagem que envolve também a conjunção carnal. Embora a cópula vagínica também seja ato libidinoso, não é, juridicamente, concebida como ato libidinoso diverso, sendo abrangida pela primeira figura examinada. Aliás, as duas figuras - conjunção carnal e ato libidinoso diverso - são 
espécies do gênero de libidinagem. (BITENCOURT, 2018).

Conforme se observa, tanto o crime de estupro quanto o da importunação sexual prevêem em seus respectivos artigos o "ato libidinoso". Contudo, na prática, ambos possuem aplicações em casos distintos. Basta ver que o delito de estupro ocorre quando, mediante violência ou grave ameaça, há a conjunção carnal -considerada como a cópula vaginal - ou quando há a prática de algum ato libidinoso, considerado grave, como a conjunção anal ou o sexo oral, praticados com violência ou grave ameaça. Já a importunação sexual é investida de atos libidinosos menos graves que recebem penas menores, tendo em vista a incidência do Princípio da Proporcionalidade, o qual encontra previsão em nossa Constituição Federal (1940) e que prevê a adequação entre a conduta do autor e a sua punição. Raciocínio este que é defendido por Bitencourt:

\begin{abstract}
Ato libidinoso é ato lascivo, voluptuoso, erótico, concupiscente, que pode ser, inclusive, a conhecida conjunção carnal (cópula vagínica) ou qualquer outro ato libidinoso diverso dela, por exemplo, a ejaculação, praticada na presença da vítima e até mesmo nela, "mas não com ela", e sem a sua anuência. Dentre os atos de libidinagem, pode-se destacar como os mais graves, quando praticados mediante violência física ou moral, o sexo anal e sexo oral, por representarem, nessas circunstâncias, para os mais conservadores, pelo menos, um desvirtuamento de sua finalidade funcional, e, por isso, violenta de forma mais grave a liberdade sexual individual do ser humano e a sua dignidade sexual e, por extensão, a própria dignidade humana. No entanto, as condutas tipificadoras do crime de estupro conjunção carnal e ato libidinoso diverso (sexo oral e anal) —, logicamente, estão excluídos desta infração penal - importunação sexual - quer por constituírem aquelas infrações penais, quer por sua gravidade que seria desproporcional à pena aqui cominada. (BITENCOURT, 2018).
\end{abstract}

Em consonância com o apresentado, Beccaria (1764) em sua obra "Dos Delitos e das Penas" trouxe a importância do legislador observar a proporcionalidade entre o crime e a punição correspondente, vejamos:

\footnotetext{
Se os cálculos exatos pudessem aplicar-se a todas as combinações obscuras que fazem os homens agir, seria mister procurar e fixar uma progressão de penas correspondente à progressão dos crimes. O quadro dessas duas progressões seria a medida da liberdade ou da escravidão da humanidade ou da maldade de cada nação. Bastará, contudo, que o legislador sábio estabeleça divisões principais na distribuição das penas proporcionadas aos delitos e que, sobretudo, não aplique os menores castigos aos maiores crimes. (BECCARIA, 1764, p. 45).
}

Em termos práticos, no crime de estupro há a exigência de que a prática do ato libidinoso seja cometida com violência ou grave ameaça e na importunação sexual, apenas que seja realizada sem a anuência da vítima, até porque se for cometida de forma mais grave o tipo funcionará como subsidiário, o que interpreta-se através da expressão do próprio artigo 
"se não constituir crime mais grave".

Em relação a aplicação do tipo da importunação sexual na prática, Bitencourt dispõe que:

[...] não se pode negar, que aquelas ejaculações constrangedoras praticadas - e divulgadas pela mídia - neste ano de 2018, nos coletivos paulistas, inclusive no corpo de mulheres, sem que as tenham anuído, tipificam, inegavelmente, este crime, por que preenchem todas as elementares constitutivas desta figura penal. A lamentar somente a impossibilidade de retroagir para alcançá-los, pois o Direito Penal só aplicável a fatos futuros e nunca a passados, posto que antes de sua tipificação não constituíam crimes, devendo-se respeitar o dogma da irretroatividade de norma penal incriminadora [...]Sintetizando, pela inexistência de anuência ou de consentimento da vítima, a conduta de ejacular na vítima ou na sua presença, de inopino, configura o crime de importunação sexual e justifica uma pena de dois a cinco anos de reclusão para essa conduta, que objetiva a satisfação da lascívia do autor (ou de terceiro), que age burlando ou dificultando a livre manifestação da vítima, violando a sua liberdade sexual. (BITENCOURT, 2018).

\subsection{Da distinção entre importunação sexual e a violação sexual mediante fraude}

O tipo da violação sexual mediante fraude, contida no art.215 do $\mathrm{CP}$, prevê: "Ter conjunção carnal ou praticar outro ato libidinoso com alguém, mediante fraude ou outro meio que impeça ou dificulte a livre manifestação de vontade da vítima. Pena - reclusão, de 2 (dois) a 6 (seis) anos." (BRASIL, 1940)

No referido ilícito penal, o fim de agir é a satisfação da lascívia, assim como no estupro e na importunação sexual. Mas a sua aplicação pelo intérprete exige elementos diferentes daqueles necessários para os outros delitos mencionados.

No caso da violação sexual mediante fraude, a conjunção carnal ou a prática de outro ato libidinoso com alguém pode ser cometida de duas formas, mediante fraude ou outro meio que impeça ou dificulte a livre manifestação da vontade da vítima.

O entendimento dominante é o de que nas duas formas é preciso que fique configurada a fraude, que "é o engodo, o ardil, o artifício que leva ao engano. [...] Em outros termos, a vítima precisa ser enganada pelo agente, sob pena de não se configurar a fraude." (BITENCOURT, 2014, p.71).

Assim, Bitencourt leciona que:

\footnotetext{
Não se deve descuidar do aspecto de que essa previsão genérica ou analógica-ou outro meio que impeça ou dificulte a livre manifestação de vontade da vítima- deve assemelhar-se à fraude, isto é, deve ser meio que tenha a mesma capacidade de ludibriar a vítima, desde que não chegue ao extremo de inviabilizar a sua livre manifestação de vontade. (BITENCOURT, 2014, p. 73).
}

Com base no exposto, na prática, o delido em comento será aplicado nos casos em que tenha ocorrido conjunção carnal ou outro ato libidinoso, mas que a vítima tenha sido 
enganada, ludibriada, mantida em erro. Como por exemplo, se o médicoginecologista, para satisfazer sua lascívia, tiver apalpado locais desnecessários no corpo de sua paciente, ou ainda, quando o agente se passar por outra pessoa. Bitencourt ensina:

\begin{abstract}
Necessita, para se configurar, que a vítima seja levada a situação de erro, ou nela seja mantida, quanto à identidade do sujeito ativo ou quanto à legitimidade do ato sexual. É preciso emprego de artifícios e estratagemas, criando uma situação de fato ou uma disposição de circunstâncias que torne insuperável o erro do ofendido. (BITENCOURT, 2014, p.72).
\end{abstract}

\title{
4.3 Da distinção entre importunação sexual e o ato obsceno
}

Outro tipo correlato é o ato obsceno, previsto no art. 233, e consiste em "praticar ato obsceno em lugar público, ou aberto ou exposto ao público: Pena-detenção, de três meses a um ano, ou multa."

Necessário entender que:

A ação tipificada é praticar ato obsceno, isto é, ato que ofenda o pudor público objetivamente, considerando-se o sentimento comum vigente no meio social. Obsceno é o que ofende o pudor ou a vergonha, ou seja, um sentimento de repulsa e humilhação criado por um comportamento indecoroso. Só pode ser ato obsceno aquele que se refira à sexualidade, não o caracterizando a manifestação verbal obscena. (BITENCOURT, 2014, p. 208).

Dessa forma, o crime tratado ofende o pudor público, a moralidade pública e não a liberdade sexual de um sujeito específico, como ocorre na importunação sexual. Ou seja, não há uma vítima específica, a sociedade é ofendida como um todo.

Para que tal delito reste configurado é necessário que o sujeito tenha o dolo de praticar ato obsceno em um local que tenha a consciência de que é público, aberto ou exposto ao público.

Pelo exposto, na prática, o crime reportado se diferencia da importunação sexual em razão da ofensa que não é dirigida à uma vítima em especial, mas sim a toda sociedade e por isso, não ofende a dignidade sexual de algum particular, mas sim o ultraje público, ou seja, os costumes daquele local. Sem falar que, necessariamente tem que ocorrer em local público, o que não é uma exigência no outro delito. Assim podemos citar como atos obscenos considerados em nosso corpo social: andar ou correr nu em via pública, automasturbação e expor o órgão genital em transporte público, isto é, qualquer ação de cunho sexual que fira os hábitos sociais.

Vale ressaltar que automasturbação e a exposição do órgão genital em transporte público acima citada configura ato obsceno, na medida em que não ofende a dignidade sexual 
de uma vítima determinada, pois atinge toda a sociedade, ofendendo assim, o pudor público. Ao contrário do que ocorreu com o caso de São Paulo, que ensejou a criação do crime de importunação sexual, neste o agente ejaculou no pescoço em uma determinada pessoa, ofendendo-lhe diretamente.

Por fim, colaciono a diferenciação feita pela promotora de justiça, Silvia Chakian de Toledo Santos (2018), entre a importunação sexual e os delitos de ato obsceno e estupro:

Ao optar pela expressão "praticar contra", preocupou-se o legislador em abranger todas essas modalidades, sem conflitar com o tipo penal do ato obsceno, que se configura quando o autor o pratica em local aberto ou exposto ao público, mas não contra pessoa determinada. A utilização da expressão "sem a sua anuência" também diferencia a importunação sexual do crime de estupro, onde há exigência de emprego de violência ou grave ameaça, além de haver menção expressa de que o tipo penal será subsidiário, caso o ato constitua crime mais grave. (SANTOS, 2018).

\subsection{Dos respectivos argumentos de defesa e contra a revogação do art.61 da LCP e também aqueles em relação à criação do tipo da importunação sexual}

Como já dito, antes da lei $n^{\circ} 13.718$ de 2018, -que tipificou a importunação sexual,entrar em vigor, existia a contravenção penal denominada importunação ofensiva ao pudor, que era prevista no art.61 da Lei de Contravenções Penais (LCP), sob a seguinte redação: "Importunar alguém em lugar público ou acessível ao público, de modo ofensivo ao pudorPena multa, de duzentos mil réis a dois contos de réis." (Lei das contravenções penais, art.61, Lei ${ }^{\circ} 3.688$ de 41$)$.

Além de sua pena ínfima de multa, a contravenção em análise se enquadrava na competência do Juizado Especial Criminal e por isso, conforme dispõe o art.69 da Lei $\mathrm{n}^{\circ}$ 9099/95, não cabia prisão em flagrante e nem se exigia fiança, caso, após a lavratura do termo circunstanciado de ocorrência, o agente fosse encaminhado ao Juizado ou assinasse um termo de compromisso.

Pelo que, com base nas questões explicitadas, estudiosos do Direito já viam a necessidade de um tipo penal intermediário entre os dois delitos tratados (estupro e importunação ofensiva ao pudor). Uma pena muito elevada como a de estupro ou outra muito reduzida como a da contravenção, não respeitaria o Princípio da Proporcionalidade. É o que podemos analisar a seguir:

Vários magistrados expressam a dificuldade de adequar determinadas condutas em estupro, quando poderiam configurar uma mera importunação ofensiva ao pudor. Por outro lado, há situações visivelmente intermediárias, superiores, em gravidade, à 
contravenção penal (art. 61, LCP), mas inferiores ao crime de estupro (art. 213, CP). É preciso criar figura intermediária, particularmente voltada a atos libidinosos de menor gravidade, merecedores de punição, mas sem a contundência das penas previstas para o estupro. (NUCCI, 2014, p. 685).

A promotora de Justiça, Valéria Scarence, integrante do Núcleo de Gênero do Ministério Público de São Paulo, em entrevista ao site Agência Brasil (2018), disse que "a nova lei representa o terceiro marco jurídico importante na área de defesa das mulheres, depois da edição das leis da Maria da Penha e do Feminicídio.” E ainda acrescentou:

Essa lei surge em razão de duas graves lacunas da nossa legislação que não previa especificamente nem a conduta de importunação sexual, conhecida vulgarmente como assédio na rua, e a conduta de divulgação de cena íntima ou cena de estupro. São fatos de muita gravidade, mas que não encontravam correspondente na lei. Os efeitos já se sentem imediatamente. Já foram feitas várias prisões, toda a população está comentando, então essa lei vem ao encontro do anseio da população. (BRASIL, 2018).

Grupos de defesa das mulheres também clamavam pela criação do tipo da importunação sexual. Conforme a fundadora e vice-presidente do Instituto Maria da Pena (IMP), Regina Célia Barbosa, expressou em sua entrevista concedida ao site Agência Brasil:

É algo que vem fortalecer nossas ações. [O projeto] ampliou a identificação de crimes que antes era constrangedor mencionar, porque não havia registro no Código Penal. Temos agora como redefinir critérios de denúncia, de fiscalização e, consequentemente, de atuação, tanto das políticas públicas, quanto da sociedade. (BRASIL, 2018).

Já outros, por mais que concordem com a criação do novo tipo penal, não coadunam com a revogação do art.61 da LCP. É o que a Promotora do Grupo de Enfrentamento à Violência Doméstica e Familiar do MP de São Paulo, Chakian, argumentou em seu artigo publicado no site CONJUR:

\begin{abstract}
Por outro lado, a revogação expressa da contravenção de importunação ofensiva ao pudor do artigo 61 do Decreto-Lei 3.688/41 (Lei das Contravenções Penais) deve trazer dificuldade no enquadramento legal de comportamentos mais brandos que aqueles previstos no novo tipo de importunação sexual, como é o caso das "cantadas" grosseiras ou grotescas, que atentam contra a dignidade da ofendida, causando constrangimento e até temor. (SANTOS, 2018).
\end{abstract}

Do mesmo modo que muitos defendem que a criação do novo tipo era necessária, outros ressaltam a incapacidade de solução do problema pela mera tipificação, apontando a necessidade de programas educativos.

Como por exemplo, a doutora em Sociologia e pós doutora em estudo de gênero, Pasinato, desacredita que a lei será empregada na prática, entendendo que esta é apenas um retrato da sociedade punitivista. E por outro lado, defende que além da responsabilização 
através da punição é preciso contar com educação e programaspreventivos para que se tenha o efeito pretendido, conforme se verifica em um trecho retirado da entrevista concedida ao site do Agência Brasil:

\begin{abstract}
Wania Pasinato julga ainda que a nova lei dificilmente será aplicada porque traz penas muito altas. Tal configuração, para Wania, responde a um anseio conservador e punitivista da sociedade."Não é a tipificação de um comportamento como crime que vai contribuir para diminuir a violência contra as mulheres", comenta Wania. [...] A pesquisadora reconhece que a lei pode facilitar o trabalho do sistema de justiça na condução destes casos, mas defende a integração de ações de prevenção, promoção de direitos, além da responsabilização dos que praticam a violência. "Temos que investir na educação. Não podemos continuar querendo enfrentar a violência contra a mulher se a gente não assume este compromisso de que a questão de igualdade de gênero tem que ser discutida nas escolas. A responsabilização é uma via, não pode ser a única e nem a mais importante e não pode acontecer isoladamente".[...] Wania avalia ainda que a lei deve ser melhor discutida com representantes da sociedade civil e afirma que a questão da violência contra a mulher será melhor combatida se forem adotadas, em conjunto com a penalização, medidas preventivas e educativas. (BRITO, 2018b).
\end{abstract}

Da mesma forma, a promotora de justiça, Chakian (2018), defendeu que além da legislação é preciso que haja uma mudança de consciência das pessoas, pois a lei sozinha é inapta para resolver toda a questão. Vejamos:

[...] a legislação penal é parte dessa transformação da cultura, mas sem a mudança de consciência da sociedade, a lei sozinha não tem poder para interromper todo o ciclo de violência que cometido contra a mulher. "As mulheres ainda hoje são mortas, são estupradas, não são resguardadas em seus direitos humanos mais básicos. O direito penal deve estar atento à realidade, mas também é preciso a adoção de novas posturas." [...] Sílvia Chakian destacou que não adianta, por exemplo, uma lei que estabelece que matar mulher por circunstância de gênero é feminicídio. Ela ressaltou que se uma mulher gritar por socorro na presença de câmeras e vizinhos, como ocorreu recentemente com a advogada morta supostamente pelo marido no Paraná, é preciso interferir. "Se a sociedade ainda hoje não interfere, é sinal de que essa sociedade acredita que a questão da violência contra a mulher é normal ou uma questão familiar, não é uma questão de Estado e de responsabilidade nossa, da sociedade. (SANTOS, 2018).

Zapater, também defendeu a mudança de comportamento do corpo social:

Sobre a crença de que essa tipificação vai reduzir a conduta, isso não se verifica em crime nenhum. Na própria justificativa do projeto, a deputada Laura Carneiro [DEM-RJ] fala que o fato de o crime de estupro ter se tornado crime hediondo não diminuiu a sua prática. O próprio legislador coloca que agravar as penas não gera resultado, mas insiste nessa mesma estratégia. É aquilo em que a gente sempre insiste: enquanto a gente não tiver mudança cultural, de pensamento e do próprio sistema de justiça para receber as mulheres vítimas de violência, não sei se vai se conseguir o impacto que, provavelmente, é o esperado - reduzir esse tipo de violência. (LIMA, 2018).

Conforme demonstrado, há argumentos que enunciam que a criação do crime de 
importunação sexual era relevante e também necessária para suprimir uma lacuna do ordenamento penal, bem como outros que defendem que somente a tipificação não é capaz de resolver a violência sexual que assola a nossa sociedade, pois também é preciso mudanças culturais e de consciência dos cidadãos. Tem-se ainda os que não acreditam que ter revogado o art.61 da LCP foi uma medida acertada. De toda forma, o delito já faz parte do nosso ordenamento jurídico e está em vigor desde setembro de 2018, tutelando as condutas que antes não possuíam um tipo específico.

\section{CONSIDERAÇÕES FINAIS}

Com a elaboração da presente monografia foi possível analisar de perto as peculiaridades do tipo penal denominado importunação sexual, o qual se apresenta como uma novidade legislativa.

Muitos operadores do Direito defendiam a necessidade da criação do novo tipo, ao argumento de que havia uma lacuna na lei e por isso, certas vezes, assédios em que ocorria o constrangimento da vítima, mas sem haver o emprego de violência ou grave ameaça, acabavam por caírem nessa brecha da norma e por isso eram punidos de forma desproporcional.

Outros estudiosos advogam que apenas a responsabilização através do Direito Penal não é capaz de resolver o problema, pois o cenário da violência de cunho sexual, principalmente contra a mulher, está arraigado em nossa cultura, o que foi verificado ao longo do capítulo denominado "histórico dos crimes sexuais". Dessa forma, defendem que é necessária uma mudança comportamental, através de medidas preventivas e educativas, formando assim, um novo costume social.

Fato é que o artigo supriu uma lacuna que existia em nosso ordenamento penal. Agora, as vítimas que sofrerem assédios sexuais, inclusive aqueles que ocorrerem em espaço público, terão respaldo legal para que o agressor seja devidamente responsabilizado. Contudo, observa-se que a lei é apenas uma das vias a serem adotadas no combate ao obstáculo, sendo inapta a resolver a questão por completo. Prova disso foi um dos dados apresentados no trabalho, com apenas três dias da entrada em vigor da lei, 29 (vinte e nove) casos de importunação sexual foram registrados em São Paulo.

Sendo assim, é necessário mudar a visão de que o desrespeito à liberdade sexual, em especial a da mulher, é algo normal. Enquanto a questão for tratada como natural, continuaremos tendo vítimas desse delito que fere a dignidade e liberdade sexual. Por isso se faz importante o investimento em educação, prevenção e em discussões de gêneros, para que 
uma nova consciência social seja construída.

Além do mais, com base no estudo realizado, tem-se que o bem jurídico que o crime de importunação sexual pretende defender é o da liberdade sexual. Tal bem jurídico objetiva garantir que todo indivíduo possa exercer a sua sexualidade de forma livre, podendo assim, escolher ou recusar seus parceiros. Nesse sentido, entende-se que o tipo em tela atende tanto a dignidade quanto a liberdade sexual, na medida que visa coibir que o agressor aja da forma desrespeitosa para com a vítimaa fim de satisfazer sua lascívia, ferindo tais bens jurídicos. Pois, a partir do momento que o agente pratica algum ato libidinoso sem anuência da outra parte, ele está invadindo a sua liberdade de escolher com quem e como se relacionar, ou ainda, o direito que ela possui de escolher não se relacionar.

Outro ponto que corrobora com a afirmação de que a importunação sexual atende aos bens jurídicos da liberdade e da dignidade sexual está na comparação realizada no último capítulo entre o crime referido e os seus tipos correlatos. Diante de fatos reais, as condutas como, ejaculação furtiva, “encoxadas”, apalpamento de áreas íntimas, entre outras citadas ao longo do trabalho, somente se encaixam nas elementares do tipo em voga. Dessa forma, caso não houvesse o tipo aqui analisado, os frequentes atos libidinosos ocorridos sem a anuência da vítima continuariam sendo punidos, como já visto, sem um adequado equilíbrio, ora como estupro, ora como importunação ofensiva ao pudor. Ou então, nem mesmo seriam punidos, por não se enquadrarem integralmente em nenhum tipo, pelo que a proteção à liberdade sexual ficaria prejudicada.

Por fim, conclui-se que a criação do tipo da importunação sexual foi necessária para cobrir uma lacuna legislativa que estava presente em nosso ordenamento e mais, atendendo aos bem jurídico da liberdade sexual e dessa forma protegendo também a dignidade sexual da pessoa humana. Tendo em conta que foi possível visualizar através do trabalho que nenhum outro delito da nossa legislação abarca, na prática, as condutas enquadradas como importunação sexual. Porém, foi compreendido que apenas a responsabilização não basta, ela é apenas um dos caminhos. Para que esse tipo de violência cesse é preciso, sobretudo, de uma conscientização do corpo coletivo.

\section{REFERÊNCIAS}

ACTION AD. Em pesquisa da ActionAid, 86\% das brasileiras ouvidas dizem já ter sofrido assédio em espaços urbanos. ActionAd, 24 maio 2016. Disponível em: http://actionaid.org.br/na_midia/em-pesquisa-da-actionaid-86-das-brasileiras-ouvidas-dizemja-ter-sofrido-assedio-em-espacos-urbanos/. Acesso em: 20 Nov. 2018 
BECCARIA, Cesare. Dos delitos e das penas. São Paulo, eBooks Brasil, 2001. Disponível em: http://www.dominiopublico.gov.br/download/texto/eb000015.pdf. Acesso em: 20 Out. 2018.

BITENCOURT, Cezar Roberto. Anatomia do crime de importunação sexual tipificado na Lei 13.718/2018. Boletim de Notícias ConJur, 30 set. 2018. Disponível em:

https://www.conjur.com.br/2018-set-30/cezar-bitencourt-anatomia-crime-importunacaosexual. Acesso em: 22 Out. 2018.

BITENCOURT, Cezar Roberto. Tratado de direito penal: parte especial 4: dos crimes contra a dignidade sexual até os crimes contra a fé pública. 8. ed. São Paulo: Saraiva, 2014.

BITENCOURT, Cezar Roberto. Tratado de direito penal: parte especial 4: dos crimes contra a dignidade sexual até os crimes contra a fé pública. 11. São Paulo: Saraiva, 2016.

BRASIL. Código Penal (1940). Decreto-Lei no 2.848, de 7 de dezembro de 1940. Código Penal. Diário Oficial da União, Brasília, 31 dez.1940. Disponível em: http://www.planalto. gov.br/ccivil_03/Decreto-Lei/Del2848.htm. Acesso em: 13 Nov. 2018.

BRASIL. Lei n ${ }^{\circ} 12.015$, de 7 de agosto de 2009. Altera o Título VI da Parte Especial do Decreto-Lei no 2.848, de 7 de dezembro de 1940 - Código Penal, e o art. 1o da Lei no 8.072, de 25 de julho de 1990, que dispõe sobre os crimes hediondos, nos termos do inciso XLIII do art. 5o da Constituição Federal e revoga a Lei no 2.252, de 1o de julho de 1954, que trata de corrupção de menores. Diário Oficial da União, Brasília, 10 Ago. 2009.

BRASIL. Lei no 13.718, de 24 de setembro de 2018. Altera o Decreto-Lei no 2.848 , de 7 de dezembro de 1940 (Código Penal), para tipificar os crimes de importunação sexual e de divulgação de cena de estupro, tornar pública incondicionada a natureza da ação penal dos crimes contra a liberdade sexual e dos crimes sexuais contra vulnerável, estabelecer causas de aumento de pena para esses crimes e definir como causas de aumento de pena o estupro coletivo e o estupro corretivo; e revoga dispositivo do Decreto-Lei $n^{\circ} 3.688$, de 3 de outubro de 1941 (Lei das Contravenções Penais). Diário Oficial da União, Brasília, 25 Set. 2018.

BRASIL. Lei no 9099, de 26 de setembro de 1995. Dispõe sobre os Juizados Especiais Cíveis e Criminais e dá outras providências. Diário Oficial da União, Brasília, 27 set. 1995. Disponível em: http://www.planalto.gov.br/ccivil_03/LEIS/L9099.htm. Acesso em: 20 Nov. 2018.

BRASIL. Senado Federal. Parecer n ${ }^{\circ}$ 524, de 2016. De Plenário, em substituição às Comissões de Direitos Humanos e Legislação Participativa e de Constituição, Justiça e Cidadania, sobre o Projeto de Lei do Senado $n^{\circ} 618$, de 2015, da Senadora Vanessa Grazziotin, que acrescenta o art. 225-A ao Decreto-Lei n 2.848, de 7 de dezembro de 1940 Código Penal, para prever causa de aumento de pena para o crime Disponível em: https://legis.senado.leg.br/sdleggetter/documento?dm=4777168\&ts=1539781702344\&disposition=inline. Acesso em: 28 Out. 2018.

BRASIL. Senado Federal. Projeto de Lei do Senado de 2015. Acrescenta o art. 225-A ao Decreto-Lei no 2.848, de 7 de dezembro de 1940 - Código Penal, para prever causa de aumento de pena para o crime de estupro cometido por duas ou mais pessoas. Disponível em: 
https://legis.senado.leg.br/sdleggetter/documento?dm=2917053\&ts=1539781701949\&disposition=inline. Acesso em: 02 Nov. 2018.

BRASIL. Senado Federal. Projeto de Lei n⿳0 618/2015. Disponível em: https://legis.senado.leg.br/sdleggetter/documento?dm=4777134\&ts=1539781702107\&disposition= inline. Acesso em: 01 Nov. 2018.

BRASIL. Senado Federal. Substitutivo da Câmara dos Deputados n 2, de 2018. Tipifica os crimes de importunação sexual e de divulgação de cena de estupro; altera para pública incondicionada a natureza da ação penal dos crimes contra a dignidade sexual; estabelece causas de aumento de pena para esses crimes; cria formas qualificadas dos crimes de incitação ao crime e de apologia de crime ou criminoso; e revoga dispositivo do Decreto-Lei ${ }^{\circ} 3.688$, de 3 de outubro de 1941 (Lei das Contravenções Penais). Disponível em:

https://www25.senado.leg.br/web/atividade/materias/-/materia/132479. Acesso em: 02 Nov. 2018.

BRITO, Débora. Especialistas comemoram criminalização de abusos sexuais. Agência Brasil, 09 ago. 2018a.Disponível em: http://agenciabrasil.ebc.com.br/direitoshumanos/noticia/2018-08/especialistas-comemoram-criminalizacao-de-abusos-sexuais. Acesso em: 24 Out. 2018.

BRITO, Débora. Nova lei de importunação sexual pune assédio na rua. Agência Brasil, 29 set. 2018b.Disponível em: http://agenciabrasil.ebc.com.br/direitos-humanos/noticia/201809/nova-lei-de-importun acao-sexual-pune-assedio-na-rua. Acesso em: 24 Out. 2018. COSTA, Álvaro Mayrink. Breves Apontamentos sobre a Reforma dos Crimes contra a Dignidade Sexual da Pessoa Human. Revista da EMERJ, Rio de Janeiro, v. 13, n. 49, p. 2950, 2010. Disponível em:

http://www.emerj.tjrj.jus.br/revistaemerj_online/edicoes/revista49/Revista49_29.pdf. Acesso em: 24 Out. 2018.

DIAS, Thaisa Mangnani; JOAQUIM, Evandro Dias. O problema da prova nos crimes contra a dignidade sexual. Revista JurisFIB, Bauru, v. 4, ano 4, p. 291-310, dez. 2013. Disponível em: http://www.revistajurisfib.com.br/artigos/1395809029.pdf. Acesso em: 18 Nov. 2018. G1. Entidades defendem juiz após libertação de homem que ejaculou sobre mulher em ônibus na Paulista.São Paulo:, G1, 01 set. 2017. Disponível em: https://g1.globo.com/saopaulo/noticia/entidades-defendem-juiz-apos-libertacao-de-homem-que-ejaculou-sobremulher-em-onibus-na-paulista.ghtml. Acesso em: 24 Out. 2018

LIMA, Juliana Domingos. Ejacular em uma mulher sem consentimento é estupro?: O que diz a lei.Nexo, 31 ago. 2017. Disponível em: https://www.nexojornal.com.br/expresso/2017/08/31/Ejacular-em-uma-mulher-semconsentimento-\%C3\%A9-estupro-O-que-diz-a-lei. Acesso em: 24 Out. 2018.

MAGNENTI, Marcos. Saiba o que é importunação sexual e o que mudou com a nova lei sobre assédio. Folha de S. Paulo, 21 out. 2018. Disponível em:

https://www1.folha.uol.com.br/cotidiano/2018/10/saiba-o-que-e-importunacao-sexual-e-oque-mudou-com-a-nova-lei-sobre-assedio.shtml. Acesso em: 26 Out. 2018. 
NUCCI, Guilherme de Souza. Código Penal comentado. 8. ed. São Paulo: Revista dos Tribunais, 2008.

NUCCI, Guilherme de Souza. Crimes contra a dignidade sexual. 3. ed. São Paulo: Revista dos Tribunais, 2009.

NUCCI, Guilherme de Souza. Curso de direito penal. Rio de Janeiro: Sindicato Nacional dos Editores de Livros, 2017. 3 v.

NUCCI, Guilherme de Souza. Manual de direito penal. 10 ed. Rio de Janeiro: Forense, 2014.

SANTOS, Silvia Chakian de Toledo. Novos crimes sexuais, a Lei 13.718/18 e a questão de gênero na aplicação do Direito. Consultor Jurídico, 4 out. 2018. Disponivel em: https://www.conjur.com.br/2018-out-04/silvia-chakian-novos-crimes-sexuais-lei137182018:// www.tjsp.jus.br/Noticias/Noticia?codigoNoticia=16826\&pagina=1. Acesso em: 18 Nov. 2018.

SÃO PAULO, Tribunal de Justiça. TJSP defende debate sobre legislação criminal. Notícias, 02 set. 2017. Disponível em:

http://www.tjsp.jus.br/Noticias/Noticia?codigoNoticia=16826\&pagina=1. Acesso em: 18 Nov. 2018.

TORRES, José Henrique Rodrigues. Dignidade sexual e proteção no sistema penal. Journal of Human Growth and Development, São Paulo, v. 21, n. 2, p. 185-188, 2011. Disponível em: http://pepsic.bvsalud.org/pdf/rbcdh/v21n2/01.pdf. Acesso em: 18 Nov. 2018. 